(c) American Dairy Science Association, 2005.

\title{
Plasma Lipid Concentrations in Preruminant Calves Fed Whole Milk with Whey Protein Isolate
}

\author{
S. Kushibiki, ${ }^{1}$ H. Shingu, ${ }^{2}$ T. Komatsu, ${ }^{1}$ F. Itoh, ${ }^{1}$ T. Hayashi ${ }^{3}$ and K. Hodate ${ }^{4}$ \\ ${ }^{1}$ Department of Animal Physiology and Nutrition, \\ National Institute of Livestock and Grassland Science, \\ Tsukuba 305-0901, Japan \\ ${ }^{2}$ Department of Animal Production and Grasslands Farming, \\ National Agricultural Research Center for Tohoku Region, \\ Morioka 020-0198, Japan \\ ${ }^{3}$ Department of Information Science and Technology, \\ National Agricultural Research Center, Tsukuba, 305-8666, Japan \\ ${ }^{4}$ School of Veterinary Medicine and Animal Sciences, \\ Kitasato University, Towada 034-8628, Japan
}

\section{ABSTRACT}

The objective was to investigate the acute effects of retinol acetate added to whey protein isolate (WPI) on postprandial changes in plasma retinol (experiment 1) and the acute effects of milk fat added to WPI on triglyceride (TG), chylomicrons and very low density lipoprotein (VLDL), and fatty acid concentrations (experiment 2 ) in suckling calves at 1 and $6 \mathrm{wk}$ of age. In experiment 1, 16 Holstein male calves were alloted to 2 equal groups. On the days of measurement, the calves were fed at $0900 \mathrm{~h}$ whole milk [4\% of body weight (BW)] mixed with vitamin A acetate (500,000 IU) with or without WPI ( $0.04 \%$ of BW). At 1 wk of age, significantly higher postfeeding concentrations of plasma retinol were observed in the calves fed milk with WPI. At 6 wk of age, no differences in the plasma retinol concentrations were observed between 2 groups. On the days of measurement in experiment 2, 16 male calves were fed at $0900 \mathrm{~h}$ whole milk ( $4 \%$ of BW) with added milk fat prepared by centrifugation from whole milk ( $2 \%$ of BW) with or without WPI $(0.04 \%$ of BW). The milk supplemented with fat was prepared on the day before the measurement. At $1 \mathrm{wk}$ of age, significant higher postfeeding concentrations of plasma TG concentrations were obtained in the calves fed WPI than in the control calves, immediately after the meal or from $7 \mathrm{~h}$ later onward. Plasma chylomicrons and VLDL concentrations at $1 \mathrm{wk}$ of age were significantly higher in the WPI-fed group than in the control group at $8 \mathrm{~h}$ postfeeding. In the calves with the WPI diet, plasma concentrations of myristic, palmitic, stearic, oleic, and linoleic acids at $1 \mathrm{wk}$ of age were significantly higher

Received June 27, 2004.

Accepted November 9, 2004.

Corresponding author: Shiro Kushibiki; e-mail: mendoza@ affrc.go.jp.

than those in the control calves at $8 \mathrm{~h}$ after feeding. However, chylomicrons and VLDL, and fatty acid concentrations did not differ between the 2 groups after feeding at 6 wk of age. Results indicate that WPI increases plasma lipid concentration of preruminant calves only at $1 \mathrm{wk}$ of age. These data are interpreted to indicate that WPI enhances mainly lipid uptake in the intestines of neonatal calves.

(Key words: whey protein isolate, retinol, triglyceride, fatty acid)

Abbreviation key: $\mathbf{T G}=$ triglyceride, $\mathbf{V L D L}=$ very low density lipoprotein, $\mathbf{W P C}=$ whey protein concentrate, $\mathbf{W P I}=$ whey protein isolate.

\section{INTRODUCTION}

Whey is a highly nutritious by-product of the cheese industry that can be used in animal feeds in a variety of forms such as liquid whey, dried whey, or dried whey products (Sienkiewicz and Riedel, 1990). In addition, whey products, such as whey protein concentrate (WPC) and whey protein isolate (WPI), have been obtainable for several years by membrane processing (Morr and Ha, 1993). These products contain 35 to $90 \%$ protein (Morr and Ha, 1993). Whey protein isolate is manufactured by a stirred-bed ion exchange adsorption process, and contains higher protein and proportionately lower concentrations of lactose and minerals than WPC (Morr and Ha, 1993). Whey proteins can also be recovered by precipitation techniques in a native form, that is, in a physiologically nutritious form, and can be used for animal feeding as well as for human nutrition (Sienkiewicz and Riedel, 1990). Calves fed WPC in several trials had greater BW gain than calves fed control milk without WPC (Mee et al., 1996; Lammers et al., 1998). Whey protein concentrate and WPI have better AA profiles for growing calves and higher bioavailabil- 
ity than dried skim milk or casein (Sienkiewicz and Riedel, 1990). Therefore, the current primary protein source in milk replacers is the low-grade WPC that contains 35 to $45 \%$ protein (Morr and $\mathrm{Ha}, 1993$ ).

Whey contains a multitude of proteins such as $\beta$ LG, $\alpha$-LA, albumin, and immunoglobulins (Wong and Watson, 1995). Over 50\% of the total whey protein content in cow milk is represented by $\beta$-LG, a protein that is not present in human milk (Perez and Calvo, 1995). The biological function of this protein is not known in detail, but the functional properties of WPC and WPI can, for the most part, be attributed to the properties of $\beta$-LG (Sienkiewicz and Riedel, 1990). Several studies have indicated that $\beta$-LG can bind to retinol, triglyceride (TG), and long-chain fatty acids in vitro (Puyol et al., 1991; Perez and Calvo, 1995). In a previous study, calves fed $\beta$-LG had significantly higher concentrations of plasma retinol and TG than control calves at $10 \mathrm{~d}$ of age (Kushibiki et al., 2001). These data suggest that $\beta$ LG enhances the intestinal uptake of retinol and TG in preruminant calves. Information is lacking regarding the effects of WPC or WPI supplementation on lipid metabolism in calves, although WPC has replaced dried skim milk as the most commonly used milk protein source in the feed industry.

In the present study, calves were fed whole milk with or without WPI in the preruminant phase ( $1 \mathrm{wk}$ of age) and transitional phase ( $6 \mathrm{wk}$ of age). The objective was to investigate the acute effects of retinol acetate added to WPI on postprandial changes in plasma retinol (experiment 1) and the acute effects of milk fat added to WPI on TG, chylomicron and very low density lipoprotein (VLDL), and fatty acid concentrations (experiment 2 ) in suckling calves at 1 and 6 wk of age.

\section{MATERIALS AND METHODS}

\section{Calf Management}

Thirty-two Holstein male calves (16 calves for each of 2 experiments) were used in the present study. All calves were removed from their dams immediately after birth and given colostrum within $2 \mathrm{~h}$. They received dam's milk (2 to $3 \mathrm{~kg} / \mathrm{d}$ ) as colostrum from d 0 to 3 . The calves were housed in individual indoor pens and had free access to fresh water. They were fed whole milk daily at $10 \%$ of BW $(0900 \mathrm{~h}, 4 \% ; 1600 \mathrm{~h}, 6 \%)$ from $4 \mathrm{~d}$ to $6 \mathrm{wk}$ of age except for the days of measurement. The calves were weighed once weekly at a constant time of the day, and were cared for according to the Guide for the Care and Use of Agricultural Animals in Agricultural Research of the Tohoku National Agricultural Research Center for the Tohoku Region throughout the period from $4 \mathrm{~d}$ to $6 \mathrm{wk}$ of age.

\section{Experimental Design}

Experiment 1. The calves $(\mathrm{n}=16)$ were divided into 2 groups of 8 animals each and used to investigate the acute effect of dietary WPI on the plasma retinol concentration at 1 and $6 \mathrm{wk}$ of age (mean BW $\pm \mathrm{SE}$; $40.1 \pm 2.2 \mathrm{~kg}$ and $63.2 \pm 2.5 \mathrm{~kg}$, respectively). The WPI powder (Morinaga Milk Industry Co., Ltd., Meguro, Tokyo, Japan) formulated to contain whey protein, 91.4\% (in $\beta$-LG; $58.0 \%, \alpha$-LA; $25.5 \%$, albumin; $4.4 \%$ ), lipid, $0.5 \%$; and lactose, $0.9 \%$ was used in this study. On the days of measurement, the calves were fed whole milk (Holstein) at $4 \%$ of BW with or without WPI at $0900 \mathrm{~h}$, but they were not fed at $1600 \mathrm{~h}$. The WPI at $0.04 \%$ of BW was dissolved in whole milk mixed with vitamin A acetate (500,000 IU). On the days of measurement, a catheter was inserted in the left jugular vein of each calf at $0700 \mathrm{~h}$, and was maintained by flushing with heparinized saline solution (10 units of sodium heparin/mL of saline). Blood samples $(4 \mathrm{~mL})$ were collected from the catheter into heparinized tubes just before feeding $(0 \mathrm{~h})$, at 0.5 and $1 \mathrm{~h}$, then hourly until $12 \mathrm{~h}$, and finally $24 \mathrm{~h}$ after the feeding. Samples were cooled on ice after collection. Within $2 \mathrm{~h}$ of collection, samples were centrifuged $(25 \mathrm{~min}$ at $1600 \times \mathrm{g})$ at $4^{\circ} \mathrm{C}$, and plasma was harvested. Plasma samples were then frozen and stored at $-20^{\circ} \mathrm{C}$ until they were analyzed for retinol.

Experiment 2. The calves $(\mathrm{n}=16)$ were divided into 2 groups of 8 animals each and were used to investigate the acute effect of dietary WPI on plasma TG, chylomicron and VLDL (as the sum of the TG, cholesterol ester, free cholesterol, and phospholipid concentrations), and fatty acid concentrations at $1 \mathrm{wk}(39.4 \pm 2.0 \mathrm{~kg})$ and 6 wk of age $(61.9 \pm 2.7 \mathrm{~kg})$. On the days of measurement, the calves were offered Holstein whole milk at $4 \%$ of BW, with added milk fat ( $2 \%$ of BW, final 47 to $52 \mathrm{~g} /$ L), with or without WPI at $0900 \mathrm{~h}$, but they were not fed at $1600 \mathrm{~h}$. The milk fat supplement was obtained by centrifugation $(25 \mathrm{~min}$ at $1600 \times \mathrm{g}$ ) of whole milk (Kushibiki et al., 2001). The milk supplemented with fat was prepared on the day before the measurement, and was continuously stirred at $4^{\circ} \mathrm{C}$ until feeding. The protocols of catheterization and the blood sampling time on the days of measurement were the same ones as described for experiment 1 . Blood samples $(2 \mathrm{~mL})$ for determination of TG were collected through the catheter into tubes containing $\mathrm{Na}_{2}$-EDTA before and after feeding. Additional blood samples $(5 \mathrm{~mL})$ for analysis of chylomicrons and VLDL, and fatty acids were collected into test tubes containing $\mathrm{Na}_{2}$-EDTA before feeding ( 0 $\mathrm{h})$ and at $8 \mathrm{~h}$ after feeding. Plasma was then separated by centrifugation at $1600 \times g$ for $25 \mathrm{~min}$ at $4^{\circ} \mathrm{C}$ and stored at $-20^{\circ} \mathrm{C}$ for later determination of TG and fatty 
acids. The remainder of the plasma at 0 and $8 \mathrm{~h}$ was supplemented with $\mathrm{NaN}_{3}$ (final concentration of $0.01 \%$, $\mathrm{wt} / \mathrm{vol}$ ) and maintained at $4{ }^{\circ} \mathrm{C}$ until chylomicrons and VLDL fractionation within $3 \mathrm{~h}$.

\section{Analytical Procedures}

In experiment 1 , plasma retinol concentrations were measured by reverse-phase HPLC (Kushibiki et al., 2001). The HPLC column consisted of a $150 \times 6 \mathrm{~mm}$ CLC-ODS column (Shimadzu Co., Ltd., Tokyo, Japan) and the mobile phase was a 90:10 ( $\mathrm{vol} / \mathrm{vol})$ mixture of methanol/double-distilled water supplemented with sodium acetate $(2 \mathrm{mmol} / \mathrm{L})$.

In experiment 2, plasma TG, chylomicrons and VLDL, and fatty acids concentrations were analyzed. The concentrations of plasma TG were determined by the glycerol-3-phosphate oxidase/3, 5-dimethoxyaniline sodium method (TG-HA test, Wako Pure Chemical, Japan) using a Hitachi 7070 autoanalyzer (Hitachi Ltd., Tokyo, Japan). The protocol for chylomicrons and VLDL isolation used here has been described previously (Kushibiki et al., 2002). Bovine plasma contains small amounts of chylomicrons and VLDL, and these are usually isolated and analyzed in combination (Bauchart and Levieux, 1985; Jenkins et al., 1988). Briefly, chylomicrons and VLDL (density, $<1.006 \mathrm{~g} / \mathrm{mL}$ ) were removed from plasma by ultracentrifugal flotation for 60 min at $1,000,000 \times g$ at $15^{\circ} \mathrm{C}$. The ultracentrifugations were performed with a Beckman type MLA-130 rotor (Beckman Instruments, Fullerton, CA) in a Beckman Optima Max Ultracentrifuge. The concentrations of TG, total cholesterol, free cholesterol, and phospholipids in the chylomicrons and VLDL fraction were determined enzymatically using a Hitachi 7070 autoanalyzer. The cholesterol ester content was calculated using the relationship: cholesterol ester $=($ total cholesterol - free cholesterol) $\times 1.68$ (Kushibiki et al., 2002). The techniques used for measurement of the concentrations of the plasma fatty acids have been described previously (Kushibiki et al., 2001). Fatty acid methyl esters were analyzed by GLC in a Hewlett-Packard chromatograph model 6890 fitted with a flame ionization detector, using a column $(30 \mathrm{~m} \times 0.32 \mathrm{~mm}$ i.d.) coated with Carbowax (J\&W Scientific, Folsom, CA).

\section{Statistical Analysis}

The various characteristics (plasma retinol, TG, chylomicrons and VLDL, and fatty acid concentrations) studied using the different treatments were analyzed using the repeated measures ANOVA format outlined for the MIXED procedure of SAS (SAS Institute, 1996). The sources of variation in the model included treat- ments, sampling time, and the interaction of treatment $\times$ sampling time. Responses to dietary WPI were compared with responses to the control at each time point using this model. Differences between responses to treatments were considered significant at $P<0.05$. All data are presented as mean $\pm \mathrm{SE}$.

\section{RESULTS}

\section{Experiment 1}

At 1 and 6 wk of age, the postprandial changes of plasma retinol concentrations in the calves fed the whole milk without WPI (control) and WPI diet showed similar patterns (Figure 1). The concentrations of plasma retinol increased gradually from $2 \mathrm{~h}$ until 7 to $8 \mathrm{~h}$ postfeeding and decreased slightly until $12 \mathrm{~h}$ thereafter. Concentrations of plasma retinol returned to prefeeding levels at $24 \mathrm{~h}$ postfeeding.

At 1 wk of age, the plasma retinol concentrations of calves fed the WPI diet were higher $(P<0.05)$ at 1 to $2 \mathrm{~h}$ and between 7 and $12 \mathrm{~h}$ after feeding than those of the control calves (Figure 1A).

However, the postfeeding concentrations of plasma retinol were not different between the calves fed the WPI diet and the control diet at $6 \mathrm{wk}$ of age (Figure 1B).

\section{Experiment 2}

Plasma TG concentrations in both groups at 1 wk of age were near $10.0 \mathrm{mg} / \mathrm{dL}$ before feeding and showed transient increases at $0.5 \mathrm{~h}$ after feeding (Figure 2A). In the control calves, plasma TG decreased up to $2 \mathrm{~h}$ after the meal. In WPI-fed calves, they leveled off from 1 to $4 \mathrm{~h}$ after the meal, being higher $(P<0.05)$ than in control calves at $2 \mathrm{~h}$ only. The TG concentrations were then similar in both groups between 4 and $6 \mathrm{~h}$ after the meal, and then they decreased in control calves and increased in WPI fed calves, being higher $(P<0.05)$ in the later group between 7 and $10 \mathrm{~h}$ after the meal (Figure 2A).

In both groups of calves, plasma TG concentrations were similar at $6 \mathrm{wk}$ of age to those observed with WPI supplements at $1 \mathrm{wk}$ of age. (Figure 2B). However, the concentration of plasma TG in the calves fed the WPI diet was higher $(P<0.05)$ than that in the control calves only at $2 \mathrm{~h}$ after feeding.

Plasma chylomicrons and VLDL concentrations pre$(0 \mathrm{~h})$ and postfeeding $(8 \mathrm{~h})$ are shown in Figure 3 . At 1 wk of age, the plasma chylomicrons and VLDL concentration was greater $(P<0.05)$ at $8 \mathrm{~h}$ after feeding in the calves fed WPI than in the control calves (Figure $3 \mathrm{~A})$. At $6 \mathrm{wk}$ of age, the concentration of plasma chylomicrons and VLDL at $8 \mathrm{~h}$ after feeding was not affected by WPI diet (Figure 3B). In the calves fed the WPI 

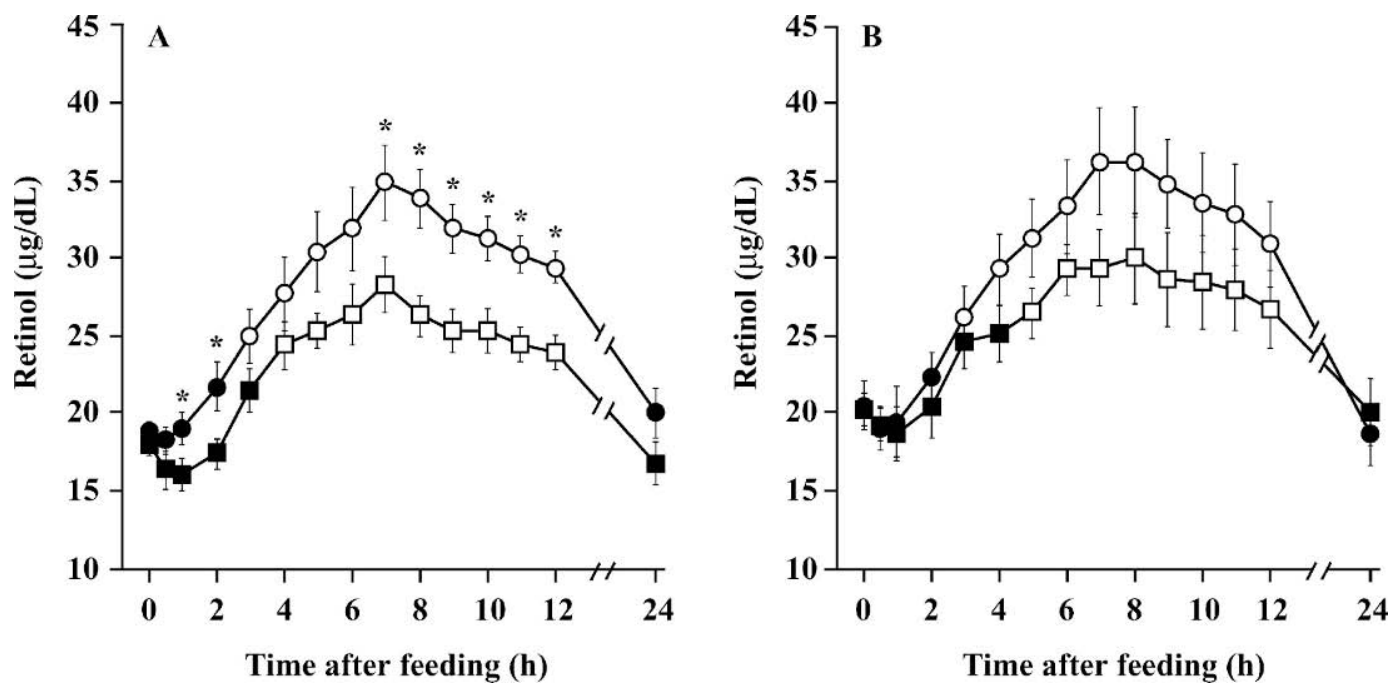

Figure 1. Postprandial changes in plasma retinol concentrations in calves fed whole milk with (circle) or without (square) whey protein isolate (WPI) in experiment 1. A. Preruminant phase (1 wk of age). B. Transitional phase (6 wk of age). Each point and bar represents the mean $\pm \mathrm{SE}$ for 8 calves. Asterisks indicate significant differences; $P<0.05$ as compared with the corresponding values for the calves fed whole milk without WPI. Open symbols indicate significant differences; $P<0.05$ compared with the value at $0 \mathrm{~h}$.

diet only and at both 1 and 6 wk of age, the plasma concentrations of chylomicrons and VLDL were greater $(P<0.05)$ at $8 \mathrm{~h}$ after feeding than before feeding.

The concentrations of plasma fatty acids in the calves fed whole milk with or without WPI are shown in Table 1. At both 1 and 6 wk of age, there were no differences in the concentrations of plasma fatty acids before feeding $(0 \mathrm{~h})$ between the WPI and control groups. At $1 \mathrm{wk}$ of age, the plasma concentrations of myristic $\left(\mathrm{C}_{14: 0}\right)$, palmitic $\left(\mathrm{C}_{16: 0}\right)$, stearic $\left(\mathrm{C}_{18: 0}\right)$, oleic $\left(\mathrm{C}_{18: 1}\right)$, and linoleic $\left(\mathrm{C}_{18: 2}\right)$ acids in the calves fed the WPI diet were higher $(P<0.05)$ at $8 \mathrm{~h}$ after feeding than those in the control calves. The concentrations of these fatty acids, particularly myristic, palmitic, stearic, and oleic acids, in the WPI-fed calves were greater $(P<0.05) 8 \mathrm{~h}$ after feeding than before feeding. At $6 \mathrm{wk}$ of age, the concentrations of plasma myristic, palmitic, and oleic acids, were higher $(P<0.05)$ both in the control and WPI-fed calves
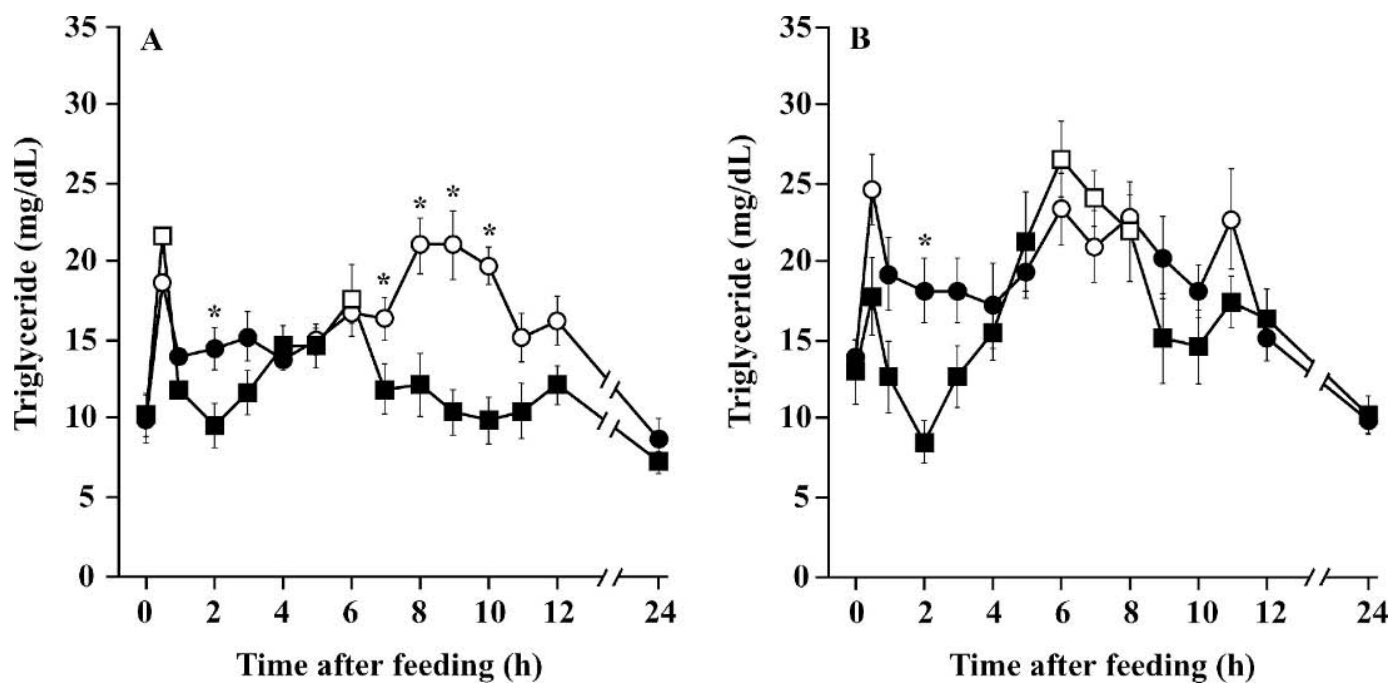

Figure 2. Postprandial changes in plasma triglyceride concentrations in calves fed whole milk with (circle) or without (square) whey protein isolate (WPI) in experiment 2. A. Preruminant phase ( $1 \mathrm{wk}$ of age). B. Transitional phase ( $6 \mathrm{wk}$ of age). Each point and bar represents the mean \pm SE for 8 calves. Asterisks indicate significant differences; $P<0.05$ as compared with the corresponding values for the calves fed whole milk without WPI. Open symbols indicate significant differences; $P<0.05$ compared with the value at $0 \mathrm{~h}$. 

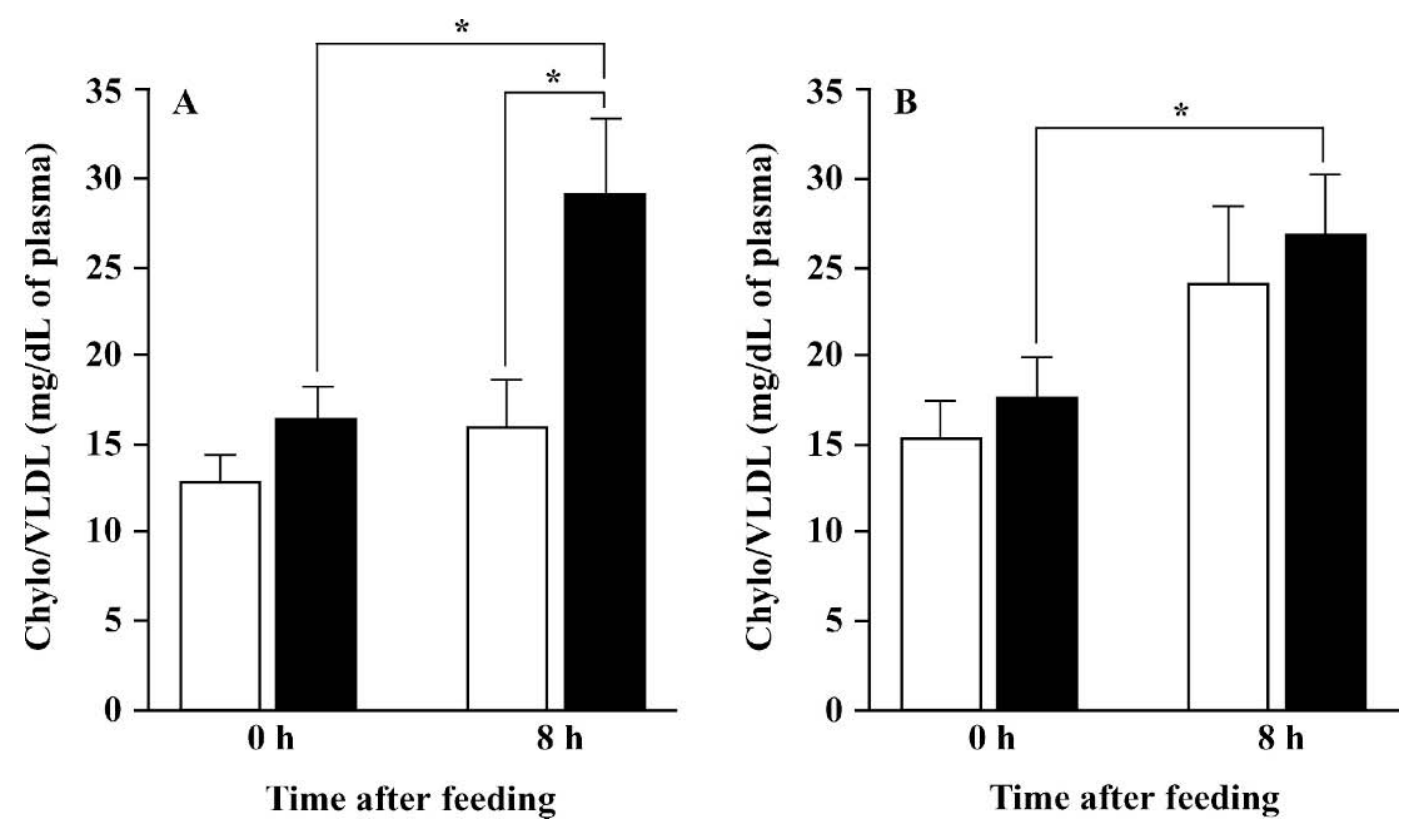

Figure 3. The concentrations of plasma chylomicrons and very low density lipoproteins (Chylo/VLDL) in calves fed whole milk with (solid bar) or without (open bar) whey protein isolate (WPI) in experiment 2. A. Preruminant phase (1 wk of age). B. Transitional phase (6 wk of age). Chylomicrons and VLDL is the sum of triglyceride, cholesterol ester, free cholesterol, and phospholipid concentrations. Each column and bar represents the mean $\pm \mathrm{SE}$ for 8 calves. Asterisks indicate significant differences; $P<0.05$ compared with the corresponding values.

$8 \mathrm{~h}$ after feeding than before feeding, as was stearic acid in the case of WPI-fed calves only. However, the comparison between the WPI and the control group did not show any significant differences.

\section{DISCUSSION}

In a previous study, preruminant calves fed $\beta$-LG had significantly higher concentrations of plasma retinol and TG than those in the calves not fed $\beta$-LG (Kushibiki et al., 2001). The present in vivo study clearly demonstrated that dietary WPI increased the postfeeding concentrations of plasma lipids in calves at $1 \mathrm{wk}$ of age.

It has been indicated that ${ }^{125} \mathrm{I}$-labeled $\beta$-LG-retinol complex binds specifically to purified microvilli prepared from 1-wk-old calf intestine (Papiz et al., 1986). This specific binding was observed only in the lower segments of the small intestine and did not occur in 6mo-old animals (Papiz et al., 1986). Moreover, it has also been reported that specific receptors for the $\beta$-LGretinol complex exist in the intestines of neonate calves (Perez et al., 1989). In an in vitro study, uptake of retinol bound to bovine $\beta$-LG was higher than that of free retinol in both the jejunum and the ileum (Said et al., 1989). Therefore, the elevation of plasma retinol concentration in the calves fed WPI in the present study suggests that $\beta$-LG could enhance the transport and absorption of retinol in the intestine of preruminant calves. The WPI in our study contained about $60 \%$ bovine $\beta$-LG.

Results obtained from the gel filtration of bovine whey incubated with retinol have shown that bovine $\alpha$-LA can bind retinol in vitro (Puyol et al., 1991). However, it is unclear whether the binding affinity of $\alpha$-LA to retinol is responsible for the postprandial changes of plasma retinol in the WPI-fed calves in vivo. Further investigations are needed, because WPI contains a relatively high abundance of $\alpha$-LA (around 25.0\%).

Concerning dietary lipid disposal, it has been known that the digestion of dietary milk fat in calves is a 2phase process (Bazin and Brisson, 1976). The first phase consists of the rapid hydrolysis of a portion of the TG in the abomasum under the action of pregastric lipase produced in saliva (Roy, 1974). The second phase involves a gradual increase in fat flow through the pylorus associated with the slow destruction of the curd postfeeding (Roy, 1974). The present study has shown that the plasma TG concentration in the calves fed the WPI-containing diet was higher than that in the control calves in both phases at $1 \mathrm{wk}$ of age. In addition, the plasma concentrations of the chylomicrons and VLDL fraction and fatty acids were elevated by WPI feeding. Bovine chylomicrons and VLDL is known to be the primary transport agent for absorbed lipid (Jenkins et al., 1988). 


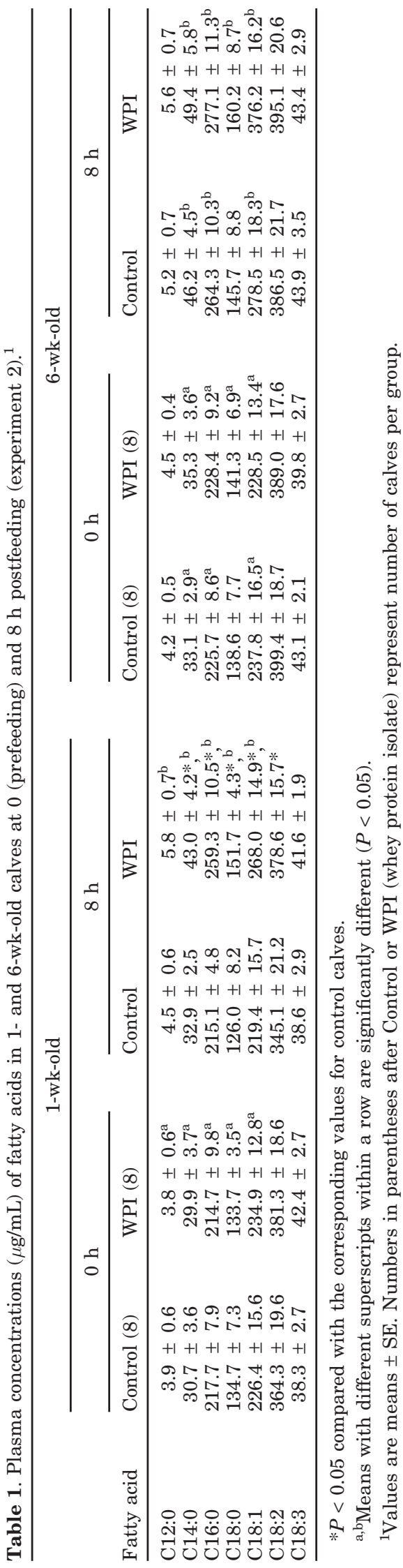

The functional properties of WPC can mostly be attributed to the properties of $\beta$-LG (Sienkiewicz and Riedel, 1990). Although the physiological function of $\beta$-LG is still unknown in detail, it has been shown that $\beta$-LG can bind retinol, long-chain fatty acids, and TG in vitro (Perez et al., 1989; Puyol et al., 1991; Perez et al., 1993). Therefore, it has been speculated that one of the biological roles of $\beta$-LG is its involvement in the digestion or transport of hydrophobic substances in newborn calves (Perez and Calvo, 1995; Creamer and MacGibbon, 1996).

Interestingly, a previous in vitro study found that the activity of pregastric lipase is increased by the presence of $\beta$-LG (Perez et al., 1992). This lipase participates in lipid digestion in the abomasum of calves during the preruminant phase (Ramsey and Young, 1961). Moreover, bovine $\beta$-LG has been reported to be quite resistant to proteolysis by digestive enzymes (Yvon et al., 1984). In particular, the binding of fatty acids to $\beta$-LG increases the conformational stability of $\beta$-LG to tryptic degradation (Puyol et al., 1993). In the present study, the action of pregastric lipase in the calves fed WPI might induce the upward shift in the TG concentrations at $2 \mathrm{~h}$ after the meal in both ages. Pregastric lipase action in calves is stimulated by suckling, and continues in the abomasums for at least $2 \mathrm{~h}$ after feeding (Edwards-Webb and Thompson, 1977). The predominant fatty acids bound to bovine $\beta$-LG are palmitic, stearic, oleic, and myristic acids (Perez et al., 1989). In the present study, the WPI diet produced an increase in the plasma concentrations of these fatty acids postfeeding compared with the control diet in the calves at $1 \mathrm{wk}$ of age. Therefore, our data suggest that the bovine $\beta$-LG in WPI can play a major biological role in milk lipid transport within the gut of preruminant calves.

On the other hand, there are data showing that the only whey proteins with the ability to bind fatty acids are $\beta$-LG and albumin (Perez and Calvo, 1995). Bovine serum albumin carries the fatty acids derived from lipolysis and delivers them to the tissues (Perez et al., 1989). However, milk albumin does not exert this effect, and fatty acids bound to it are not taken up by the tissues (Perez et al., 1989). Thus, the in vitro effect of albumin on lipid metabolism did not match the reported uptake of fatty acids in gut.

In conclusion, the present study indicates that the plasma retinol, TG, chylomicrons and VLDL, and fatty acids concentrations in calves at $1 \mathrm{wk}$ of age are increased significantly by WPI supplements. These results suggest that WPI participates in the retinol transport and lipid metabolism of preruminant calves.

\section{ACKNOWLEDGMENTS}

This research was supported by a grant from the Japan Livestock Technology Association. The authors 
are grateful to Akinori Oshibe and Eiko Touno (National Agricultural Research Center for Tohoku Region) for help with the experiments. We are also grateful to Kyoko Hodate (Institute of Livestock and Grassland Science) for advice about chemical analysis.

\section{REFERENCES}

Bauchart, D., and D. Levieux. 1985. Plasma lipoproteins of the preruminant calf. Reprod. Nutr. Dev. 25:243-250.

Bazin, R. C., and G. J. Brisson. 1976. Plasma lipids, ketone bodies, and glucose concentrations in calves fed high- and low-fat milk replacers. J. Dairy Sci. 59:1301-1305.

Creamer, L. K., and A. K. H. MacGibbon. 1996. Some recent advances in the basic chemistry of milk proteins and lipids. Int. Dairy J. 6:539-568.

Edwards-Webb, J. D., and S. Y. Thompson. 1977. A comparison of the products of lipolysis of milk fat by salivary and pancreatic lipases in vitro. Br. J. Nutr. 37:431-440.

Jenkins, K. J., G. Griffith, and J. K. G. Kramer. 1988. Plasma lipoproteins in neonatal, preruminant, weaned calf. J. Dairy Sci. 71:3003-3012.

Kushibiki, S., K. Hodate, J. Kurisaki, H. Shingu, and Y. Ueda. 2001. Effect of $\beta$-LG on plasma retinol and TG concentrations, and fatty acid composition in calves. J. Dairy Res. 68:579-586.

Kushibiki, S., K. Hodate, H. Shingu, E. Touno, and Y. Yokomizo. 2002. Alterations in lipid metabolism induced by TNF administration to dairy heifers. J. Anim. Sci. 80:2151-2157.

Lammers, B. P., A. J. Heinrichs, and A. Aydin. 1998. The effect of WPC or dried skim milk in milk replacer on calf performance and blood metabolites. J. Dairy Sci. 81:1940-1945.

Mee, J. F., K. J. O’Farrell, P. Reitsma, and R. A. J. Mehra. 1996. Effect of a WPC used as a colostrums substitute or supplement on calf immunity, weight gain, and health. J. Dairy Sci. 79:886-894.

Morr, C. V., and E. Y. W. Ha. 1993. Whey protein concentrates and isolates: Processing and functional properties. Crit. Rev. Food Sci. Nutr. 33:431-476.

Papiz, M. Z., L. Sawyer, E. E. Eliopoulos, A. C. T. North, J. B. C. Findlay, R. Sivaprasadarao, T. A. Jones, M. E. Newcomer, and
P. J. Kraulis. 1986. The structure of $\beta$-lactoglobulin and its similarity to plasma retinol- binding protein. Nature 324:383-385.

Perez, M. D., and M. Calvo. 1995. Interaction of $\beta$-lactoglobulin with retinol and fatty acids and its role as a possible biological function for this protein: A review. J. Dairy Sci. 78:978-988.

Perez, M. D., C. Diaz De Villegas, L. Sanchez, P. Aranda, J. M. Ena, and M. Calvo. 1989. Interaction of fatty acids with $\beta$-lactoglobulin and albumin from ruminant milk. J. Biochem. 106:1094-1097.

Perez, M. D., P. Puyol, J. M. Ena, and M. Calvo. 1993. Comparison of the ability to bind lipids of $\beta$-lactoglobulin and serum albumin of milk from ruminant and non-ruminant species. J. Dairy Res. 60:55-63.

Perez, M. D., L. Sanchez, P. Aranda, J. M. Ena, R. Oria, and M. Calvo. 1992. Effect of $\beta$-lactoglobulin on the activity of pregastric lipase. A possible role for this protein in ruminant milk. Biochim. Biophys. Acta 1123:151-155.

Puyol, P., M. D. Perez, J. M. Ena, and M. Calvo. 1991. Interaction of bovine $\beta$-lactoglobulin and other bovine and human whey proteins with retinol and fatty acids. Agric. Biol. Chem. 55:2515-2520.

Puyol, P., M. D. Perez, L. Mata, J. M. Ena, and M. Calvo. 1993. Effect of retinol and fatty acid binding by bovine $\beta$-lactoglobulin on its resistance to trypsin digestion. Int. Dairy J. 3:589-597.

Ramsey, H. A., and J. W. Young. 1961. Role of pregastric esterase in the abomasal hydrolysis of milk fat in the young calf. J. Dairy Sci. 44:2227-2231.

Roy, J. H. B. 1974. Problems in the nutrition of the preruminant calf. Proc. Nutr. Soc. 33:79-85.

Said, H. M., D. E. Ong, and J. L. Shingleton. 1989. Intestinal uptake of retinol: Enhancement by bovine milk $\beta$-lactoglobulin. Am. J. Clin. Nutr. 49:690-694.

SAS Institute. 1996. SAS/STAT Software. Changes and Enhancements through Release 6.11. 1996. SAS Inst., Inc., Cary, NC.

Sienkiewicz, T., and C. L. Riedel. 1990. Whey and whey utilization. Pages 44-88 in Utilization of Whey. Verlag Th. Mann, Gelsenkirchen-Buer, Germany.

Wong, C. W., and D. L. Watson. 1995. Immunomodulatory effects of dietary whey proteins in mice. J. Dairy Res. 62:359-368.

Yvon, M., I. Van Hille, and J. P. Pellisire. 1984. In vivo milk digestion in the calf abomasum. 2. Milk and whey proteolysis. Reprod. Nutr. Dev. 24:835-843. 